\title{
Donghak (Eastern Learning), Self-cultivation, and Social Transformation: Towards diverse curriculum discourses on equity and justice
}

\author{
Seungho Moon \\ Loyola University Chicago, smoon3@luc.edu
}

Follow this and additional works at: https://ecommons.luc.edu/education_facpubs

Part of the Education Commons

\section{Author Manuscript}

This is a pre-publication author manuscript of the final, published article.

\section{Recommended Citation}

Moon, Seungho. Donghak (Eastern Learning), Self-cultivation, and Social Transformation: Towards diverse curriculum discourses on equity and justice. Educational Theory and Philosophy, 49, 12: 1146-1160, 2017. Retrieved from Loyola eCommons, Education: School of Education Faculty Publications and Other Works, http://dx.doi.org/10.1080/00131857.2016.1216386

This Article is brought to you for free and open access by the Faculty Publications and Other Works by Department at Loyola eCommons. It has been accepted for inclusion in Education: School of Education Faculty Publications and Other Works by an authorized administrator of Loyola eCommons. For more information, please contact ecommons@luc.edu.

\section{(c) $\odot \odot$}

This work is licensed under a Creative Commons Attribution-Noncommercial-No Derivative Works 3.0 License. (c) Philosophy of Education Society of Australasia, 2016. 
Donghak (Eastern Learning), Self-Cultivation, and Social Transformation:

Towards Diverse Curriculum Discourses on Equity and Justice

\author{
Seungho Moon, Ed.D. \\ Assistant Professor \\ School of Education \\ Loyola University Chicago
}

Acknowledgement:

This work was supported by the Academy of Korean Studies Grants (AKS 2014-R-12)

\title{
Author Note
}

Dr. Seungho Moon is an Assistant Professor in Curriculum Studies at Loyola University Chicago. Correspondence should be addressed to Dr. Seungho Moon, Lewis Towers $11^{\text {th }}$ floor. 820 N. Michigan Ave. Chicago, IL 60611. E-mail: smoon.tc@gmail.com 1-646-724-1986. 


\section{Donghak (Eastern Learning), Self-Cultivation, and Social Transformation:}

\section{Towards Diverse Curriculum Discourses on Equity and Justice ${ }^{1}$}

Seungho Moon (Loyola University Chicago)

\section{Introduction}

This paper examines the ontology of Donghak [東學 Eastern Learning] to provide a framework for reviewing concepts of the self-other dichotomy, self-cultivation, and social transformation. Scholars interested in East Asian philosophy are eager to learn the notion of "self" drawing from various regional traditions. Donghak articulates self-other, self-cultivation, and social transformation grounded in Korean intellectual heritage rather than using the approaches common in Western forms of religion, science, and philosophy (Kim, 2004).

The purpose of this paper is to pry open an intellectual space to communicate with international philosophers and curriculum theorists regarding this urgent issue: How can curriculum theorists investigate a different epistemology and ontology when social, economic, and opportunity inequity are increasing continuously with alarming severity, both locally and globally? Donghak provides an important philosophical framework for challenging the current neoliberal, market-oriented social and curriculum practices. Pinar, Reynolds, Taubman, and Slattery (1995) re-conceptualize curriculum as a complicated conversation incorporating multiple texts with curricular discourses, including seeing the curriculum comprised of theological and international texts. Similarly, I examine the possibility of extending the current curriculum discourse by integrating international, theological texts.

\footnotetext{
${ }^{1}$ This work was supported by the Academy of Korean Studies Grant (AKS-2014-R 12). I owe this research to Drs. Suk San Yoon, Hye-Jung Jung, Moon-Hwan Oh, and Yong-Hwi Kim who participated in interviews and shared their knowledge and wisdom of Donghak. Special thanks to Yeorim Ana Hwang who supported this research as a graduate assistant.
} 
I elaborate the ways in which the democratic ideals of equity drawn from Donghak have been socio-politically implemented for social transformation. Donghak has rarely been introduced to the international audience, and this analysis of Donghak in regards to the crisis of human dignity provides a salient framework from which to review equity and social transformation issues. I articulate the major philosophical concepts of Donghak to provide a platform to elaborate specific social movements in Korea's Joseon Dynasty. The understanding of these concepts provides the ways in which the democratic ideals of human dignity and equity are socio-politically implemented for social transformation. At the end, I provide suggestions for curriculum theorists to consider as this new ontology of self-other supplies opportunities to revisit social problems from diverse perspectives.

\section{Sociopolitical Context of Donghak and Su-un}

Dramatic sociopolitical changes happened during the turn of $19^{\text {th }}$ and $20^{\text {th }}$ century in Korea. Before the transformation, the Confucian social hierarchy was rigid and a person's life was determined from birth depending on age, class, and gender. Neo-Confucianism operated as the primary, state-sponsored foundation for legal, sociopolitical, and economic practices in the Joseon Dynasty (1392-1910). Neo-Confucianism was implemented to create a healthy, supportive community through self-cultivation and practicing benevolence, righteousness, propriety, wisdom, and sincerity [仁義禮智信] (Kim, 2007). However, these ideals for sustaining a "harmonious" society were hindered by Neo-Confucianism's tendency to elevate "the position of orthodoxy, making it a state-sponsored socioreligious worldview" during Suun's lifetime (Kallander, 2013, p. xi). Few chances existed to break this hierarchy. Nevertheless, a new middle class emerged due to economic prosperity and this class did not come from the 
echelons of the high-ranking aristocracy ${ }^{2}$.

More changes were spurred when Western imperialists from France, the U.S., and Holland landed in the Korean peninsula, and Catholic missionaries accompanied the military powers for colonization. Western and Japanese imperialist and colonial powers competed against one another in the Korean peninsula. Japanese imperialism had spread into the Korean peninsula after Japan opened its doors for Westernization in 1866. Korea’s Peasant Revolution in 1894 rooted in Donghak sparked the Sino-Japanese War (1894-1895). The political leaders in the Joseon Dynasty was not able to defend this revolutionary uprising and requested Chinese forces to fight against the peasants. Chinese involvement in Korean politics brought the Japanese military into the Korean peninsula and this political conflict caused the Sino-Japanese War (Kallander, 2013). According to Chung (2007), major sociopolitical trends occurred when the existing inequity gap dramatically increased between the feudal class and the peasantry. Peasants witnessed the growth of Catholicism and its message of the "equal" status under God. These external and internal pressures challenged the feudal Confucian hierarchy during the end of Joseon Dynasty.

The founder of Donghak, Choi Je-u (1824-1864), whose honorific name is Su-un, theorized a new philosophy and theology genealogically drawn from Korea's traditional schools of thought, including Confucianism, Buddhism, Taoism, and Shamanism. Su-un was the descendant of a noble family in the Joseon Dynasty. His father was an established scholar and

${ }^{2}$ Donghak was reactionary to this hierarchical, state-sponsored aristocracy by providing equity oriented ontology and cosmology. The praxis of Donghak - connected to raising critical consciousness for the peasant and the oppressed-is similarly discussed in the current educational thoughts, such as those offered by Paulo Freire (1970) and critical theorists. Both Donghak and Freire emphasized the conscientization of the oppressed for equity and social transformation. While Freire emphasized literacy education for the peasants, Donghak provided a new way of thinking about equity issues by restructuring self-other and God-human relations. 
aristocrat, but he never attained a high-ranking official position. His father died when Su-un was 16 years old, and he suffered severely from this loss. Su-un was the male progeny of his father's third marriage and therefore was not eligible to take a high-ranking official test due to his "second citizen" status in the feudal system. In search for a new Way and truth, Su-un traveled around Korea yet witnessed sociopolitical corruptions and peasants' sufferings. He continued meditations in the mountains and riverbanks for about two decades. In 1860 in Yongdam, Gyeongju after 20 years of meditation, Su-un experienced Hanullim $^{3}$-- a pure Korean word to refer to Donghak's God. After Hanullim's divine message was revealed to Su-un, he continued with a spiritual training for another year and began teaching the Way that brought about his revelation (Kim \& Yoon, 2007). He then focused on teaching a religious awakening that sought to end social discrimination against the oppressed. Su-un's teaching opposed the ideology of the existing Confucian hierarchy. Consequently, he was arrested in December 1863 and executed on March 10, 1864. Su-un's theology and Donghak's praxis-oriented pedagogy is a still-living presence in Choendogyo ${ }^{4}$ [The Religion of the Heavenly Way].

\section{Donghak's Ontology and Social Transformation}

\footnotetext{
${ }^{3}$ Hanullim literally means the Lord who lives in heaven. In his book, The true meaning of the Lord of heaven 天主實義, Matteo Ricci (1985) translated God into Chun-ju [天主, the Lord of heaven]. Su-un uses Chun-ju in articulating his explication of deity (Kallander, 2013). Donghak's theology is profoundly different from that of Judeo-Christian rooted in monotheism. Su-un incorporates East Asian philosophy and religion in describing Hanullim. I elaborate the concept of Hanullim in the section Donghak's Ontology and Social Transformation.
}

${ }^{4}$ Byeong-hui Son, the third leader of Donghak, officially changed its name as Choendogyo to underscore its religious movement for the advancement of human dignity and independence (Kim \& Yoon, 2007). During the Japanese colonization in Korea (1910-1945), for example, Choendogyo actively participated in Korea's independence movement, educating women and children through publishing journals and magazines, and engaging in higher education. 
While experiencing the influx of Western imperialism, including Catholicism, in the Korean peninsula, Su-un established a "liberation-oriented, and socially-transformative" (Chung, 2007, p. 27) religion and philosophy. In this section, I explain three major concepts Donghak provides in rethinking self-other via Shi-chun-ju (侍天主), self-cultivation, and the social transformation of Gae-byeok (開䦕). Previously, Han (2010) introduced these three concepts by analyzing Donghak's practical philosophy, drawing from religious, personal, and communal perspectives. Partially informed by Han, I highlight an ontological interpretation of Donghak and provide a different view on social transformation grounded in this new ontology.

\section{Shi-Chun-Ju and Self-Other}

Shi-chun-ju (侍天主) is a primary concept to understand Donghak. This phrase is translated in multiple ways by interpreting its theology differently. The most common, literal translation is that "everyone serves God within him or her." It means that each person serves Hanullim within the person. The core belief in Shi-chun-ju is that all living and non-living things are dignified if they bear and serve Hanullim within them (Kim, 2002). The ontology of Shichun-ju originates from Su-un's spiritual, first-hand experience of Hanullim and listening to the message of "my heart-mind is no other than your heart-mind" (oh-shim-geuk-yeoshim 吾心㴧汝心).

In Donghak, the debate between theocentricism and anthropocentricism is oriented toward a new direction by reconceptualizing God as immanently transcendent: that is, every living and non-living thing bears and serves Hanullim. Su-un articulates his ontological foundation in major scriptures, including "Eastern Script” [Dong-gyeon-dae-jeon 東經大全] (Kallander, 2013; Kim \& Yoon, 2007) and “Songs of Yongdam” [Yong-dam-eu-sah 龍潭遺詞] (Kallander, 2013). Hanullim and individual human beings do not exist in a separate body. Su-un 
articulates the ontology of God with three letters of Shi-chun-ju: “侍 (Shi) is serving the Divine Spirit within you and recognizing that qi exists as the vital force of life. 天主 (Chun-ju) means “to respect, to serve God [Hanullim] like you do for your own parents" (Kim \& Yoon, 2007, p. 34).

In Donghak, Su-un offers a framework recognizing God as both immanent and transcendent. Hanullim resides in every human being as spirit ${ }^{5}$ (nae-you-shinryeong 內有神靈) and mutually arises through all people and the cosmos (wae-you-Giwha 外有氣化). According to Yoon (2010), Shinryeong means to keep Hanullim's pure mind in me. Giwha can be translated as to practice the virtue of Hanullim within me by combining knowledge and actions.

Lee (2014), a postcolonial theologian, interprets God's being in Donghak while highlighting its nondualistic relationship. He states, "This blurring of the boundaries between inside and outside, or the microcosmic and the macrocosmic, is what the nondualistic duality of the numinous spirit 'within' and the harmonious becoming of psychophysical energy 'without'" (p. 220). This apophatic understanding of God from within and without shows Su-un asserted no dichotomous boundaries between God and human. Lee (2014) articulates the idea of a reciprocal and interdependent, non-dualistic relationship of self-other. Su-un “implies one's becoming intimately connected to the heart of the others in relations of reciprocity and interdependent

\footnotetext{
${ }^{5}$ Christian postcolonial theology finds the common ground between Donghak's Hanullim with the Holy Spirit. Postcolonial theology argues that $q i$ theology is similar to Donghak's Hanullim because the Holy Spirit is the actual interactive agent in human lives. Despite its similarities, Hanullim is different from Christianity's mainly because God is an absolute transcendental, universal Being in Christianity. Rather than a metaphysical real being, Donghak theorizes that Hanullim is "a being in the process of becoming or in progress" (Kim, 2002, p. 169). Furthermore, Donghak challenges theocentricism by claiming the Oneness of God and humankind (人乃天). The unity of God and humankind, not the duality of them, debunks a hierarchical division of the two (Setton, 2000).
} 
becoming" (Lee, 2014, p. 221). In Donghak, the interactions among people are not anthropocentric communication among people. Rather, it is dynamic interplay of "Gods" within each of us. The inter-relationality among the subjectivities, which is operated by $q i$, challenges the Western, humanistic dichotomy of self and other.

This transcendent self-other relation is a provocative understanding about self, other, and the world. The concept of God who dwells in the finite human being implies there is a mystical oneness between man and Hanullim. The nondualistic relationship between Hanullim and human beings challenges the Western humanistic perspective. In the Western tradition, the Cartesian interrogation of self has established the understanding of a self independent from the other. Only the self who doubts his or her own consciousness is valid for recognizing the existence of selfother. The humanistic understanding of self stems from accepting a fully conscious, autonomous, and independent self and other (Miller, 2005). Unlike this humanistic understanding of selfother, Donghak challenges modernist binaries of "inside/outside" in God's existence.

Furthermore, a new ontology of self-other via Shi-chun-ju challenges the anthropocentric understanding of cosmos. Hanullim resides in all objects and the cosmos in a transcendent and immanent way. A golden rule in Donghak is: 'Respect heaven, respect humankind, and respect objects.' This teaching emphasizes that Hanullim exists in all living and non-living things in the cosmos and humankind should respect every element with the same manner of serving Hanullim within him or her.

The equal treatment for Hanullim, humankind, and all objects is possible because Hanullim is not a concrete subject-agent. Rather Hanullim as the Ultimate Energy operates in "the chaotic matrix" (Lee, 2014, p. 213). Recently, supporters of an eco-centered curriculum have revisited Donghak because of its equal respect and emphasis on heaven, humankind, and 
nature (Kim, 2007). Overall, Donghak generates new ontological questions about the nature of self, the other, and the logic of separation of self/other in humanity's lived experience. The self is not independent from the othered objects, including God. A binary division of self-other is not possible. The emphasis on the self-other mutuality has brought new insight to view the world from different angles. The self-other relationship is interpreted not only within God-human relations but also within human-human/cosmos interactions. In other words, we do not exist independently (or self-made) but in eternal dependency on the other.

\section{Su-Shim-Jung-Qi (Self-Cultivation) and Returning to God's Pure Mind}

In Donghak, a new spiritual awakening about the subject bearing Hanullim transforms the ways in which people live in the world. The ultimate task of each believer is to restore the original nature of man endowed by Hanullim and to realize God dwells in each person's heart [Shi-chun-ju]. Donghak teaches people to study one's mind and physical energy together by meditating on a God who is both immanent and transcendent in cosmos (Kim, 2006). Su-un elaborates the term of Sushim-junggi [守心正氣], a way to practice self-cultivation. Literally, Sushim-junggi means to keep the heaven's mind in each person and make the energy right. Sushim is recognizing Hanullim within a person and keeping one's Hanullim as pure, bright, and mild. Junggi is to feel the heaven's energy through the body.

In Donghak, chanting 21 letters regularly is considered an important means to practice Junggi. The incantation of 21 letters is a method to illuminate Hanullim within the individual; people reveal Hanullim within the self and through this and uncover the embodying Tao from the Ultimate Being in the cosmos (Yoon, 2007b). These letters mean, "the ultimate energy [of Hanullim] has reached me now. I pray for its descent. By realizing that I have God in me, I want to be transformed according to the will of God, and I want not to forget God's grace forever and 
want to know all truths” [至氣今至願踻大降侍天主 造化定 永世不忘 萬事知] (Kim \& Yoon, 2007, pp. 26-27).

Through self-cultivation, "everybody who perceives truth that one's mind becomes a saint to do virtue without heaven and world by changing into one's body into the heaven's energy together through an incantatory training for long" (Yoon, 2010, p. 341). Donghak is provocative in that it purports one to examine the "inside" of self by acquiring Tao from immanent God rather than searching for the truth from "outside." The truth exists within a person already. Thus, Sushim-junggi is the method of self-cultivation by which everyone who perceives Hanullim in his or her mind becomes a saint by changing his or her body into the heaven's energy through incantatory training.

Donghak's self-cultivation is highly influenced by Neo-Confucian self-cultivation in terms of underscoring the practice of sincerity and generosity. In the neo-Confucius tradition, $\mathrm{Su}$ shim refers to keeping a fundamental orientation of generosity, righteousness, courtesy, and wisdom. Junggi means to practice these four elements in our daily lives. A major difference between Donghak and Neo-Confucianism stems from Donghak's challenge to the hierarchical practice of self-cultivation dividing the sage and noble classes from the peasants. Su-un distinguishes these differences as follows: "Generosity, righteousness, propriety, and wisdom are the virtues taught by the former sages [Confucius]. Keeping in good mind and having the right spiritual force are the virtues established only by me" (Kim \& Yoon, 2007, p. 18). Thus, the learning of heart-mind in Donghak is profoundly rooted in the subject's belief that Hanullim is embodied in the subject within (內有神靈) and without (外有氣化). 


\section{Gae-Byeok and Social Transformation}

Gae-byeok, the "Beginning of a New World," (Kim, 2002, p. 158) is holistic or harmonious social transformation. The pursuit of a selfish mind (Gak-ja-we-shim; 各自爲心) exacerbates social ills and causes society to lose its correct orientation for the public good. The initiating of a new world is imperative for creating a new social order recognizing the values of all living and non-living things and practicing self-cultivation (Yoon, 2004).

This social transformation of Gae-byeok happens both on a personal level and a social level. Su-un claims this revolution comes about due to the compatibility between humans and heaven. Being re-born as a person of Hanullim is a personal-level Gae-byeok. A social necessity to create a new world by rectifying social injustice is a social-level Gae-byeok. Thus, Gae-byeok brings about a major social transformation when the desire of an individual, group, and the cosmic energy come together. Individual desire for social change does not create Gae-byeok. A dynamic interplay among individual desire, social need, and the cosmic energy is imperative.

Su-un elaborates this mystery of Gae-Byeok in Donggyeong Daejeon. He states, "the realization of the Way comes does not come from humankind. It is by faith, not by study or effort. The way exists nearby, not in a distance place. The Way is realized by sincerity, not by a mere search. Not so, yet so. The Way may appear to be distant but this is not really so" (Kim \& Yoon, 2007, p. 37). In Korean history, $1894^{6}$ is regarded as historical point at which time the

\footnotetext{
${ }^{6}$ In 1894, the Peasant Revolution in Korea was the response to harsh treatment to the peasants by the noble class and corrupt government officials. This revolution requested 12 points for the social reform. Salient points include the investigation of corrupt government officials and the punishing of guilty ones, the abolishment of slavery, permission for widows to remarry, getting rid of regional and class discrimination in job opportunities, and redistribution of land equally for farming. The 1894 revolution is the major democratic movement in Korea that provided a new vision for equal human dignity with a revolutionary turn (Kim, 2004). Although the peasant revolution itself was not successful in building a new regime and caused the Sino-Japanese War
} 
spirit of Gae-byeok was actualized in Korean society and the injustice towards the oppressed, or the peasants, was uprooted from society.

Gae-byeok is not determinism, nor does it prophesize the future. Su-un taught that Gaebyeok is the birth of new human being and fundamental change of human being through selfcultivation of sincerity, respect, and trust [誠敬信; sung, gyeong, shin]. Yoon (2010) analyzes the concept as showing the arrival of this new age is generated both from the principle of heaven and from the proper conduct of humankind. Hanullim informs the time for social transformation or new cosmic creation, yet Hanullim is not the actual creator of this change. Paradoxically, God is both the cosmic frame itself and the change itself.

Su-un emphasizes humankind's effort to keep a good mind and continue right conduct. A new beginning is possible by human beings "who transform themselves through internal spiritual change and construct a new world" (Kim, 2002, p. 165). This is the humankind's contribution of Gae-byeok. Similarly, Kim (2012) highlights the importance of the 21-letter incantation in selfcultivation. Su-un argues that human change is the beginning of social transformation and selfcultivation is the very starting point for social transformation (Kim, 2012). Gae-byeok teaches people to reflect on significant approaches for social transformation and how to prepare for the transformation in case it happens.

\section{Creating Diverse Curriculum Discourses on Equity and Social Transformation}

In this section, I analyze the ways in which Donghak provides a different framework to review urgent issues in equity and social transformation in education. I revisit equity and human dignity issues from Donghak's Shi-chunju theology. I argue that the ideal for Heavenly Earth (Ji-

(August 1894 - April 1895), sociocultural reformation happened, such as abolishing slavery and supporting a widow's right to remarry ( $\mathrm{Ra}, 2002)$. 
shang-chun-guk) is connected with major discourses in liberal theology. Donghak is meaningful to imagine a different society while creating a Cosmological Community (Dong-gui-il-che).

\section{Donghak and Equity Issues}

Donghak provides an ontological foundation of Shi-chun-ju and this ontology becomes the foundation for an egalitarian message among human beings, regardless of their social status. This emphasis on moral equity converges with modern democratic ideals, including human dignity and equity (Oh, 2003; Setton, 2000). The spiritual awakening in which "everyone possesses God [Hanullim] and serves it" provides the foundation for examining the equity of human dignity. Donghak's philosophy was subversive to a feudal system that did not conceive of all human beings as having equal value, let alone consider the equity between humankind and nature. This provocative awakening for equal human dignity extends to all people regardless of their class, gender, and age. Most notably, the emphasis on women's and children's rights in the $19^{\text {th }}$ century is exceptional. The emphasis on women's equal rights occurred at least half a century before Western activists fought for women's rights in the suffrage movement.

Donghak was a pioneer in advocating for children's rights. Even children bear and serve Hanullim within them, and adults should not treat the God with discrimination or abusive behavior. Jeong-hwan Bang is recognized as the father of children's rights movement in Korea. He coined the new term, Uh-rin-yee (children, 어린이), to respect children as human beings who have a dignity equal to that of adults. No official term existed to recognize children at the time.

Bang wrote many children's books and published a magazine, Children, in 1923. He also established Children's Day (May $5^{\text {th }}$ ) to celebrate the value of children. Bang advocated for children by implementing his educational theories emphasizing a love of life, play in nature, artistic experience, and teaching empathy with the pain of nature and society (Jung, 2014). 
Bang's support for children and children's rights aligns with Su-un's provocative idea about equal human dignity, which draws from the subject's "internal relatedness with God [Hanullim] and the external interactivity in operation among all things in the universe" (Kim, 2002, p. 168). This egalitarian message about human dignity was exceptional, considering $19^{\text {th }}$ century Korea, when position in the social hierarchy was awarded to individuals at birth, and the existing social hierarchy hindered any promotion of equal opportunity in society. Su-un actually practiced his philosophy of human dignity in his region and he was executed due to this subversive belief that went against the existing social norms.

\section{Building Ji-shang-chun-guk (Earthly Heaven) from Liberation Theology}

The heritage of Donghak led actual social transformation in $19^{\text {th }}$ and $20^{\text {th }}$ century Korea. The Donghak movement advocated agricultural land reform, a transformation of the restrictive class system, liberation of slaves, the rights of remarriage for widows, punishment of corrupt officials, and greater popular participation in local administrations. Externally, the major goal was to strengthen the nation and fight against political, imperial, and commercial exploitation from the West and Japan ${ }^{7}$. The impact of Donghak is evident in the very observation that the peasant movement featuring such exalted democratic ideals could spring forth from Korean soil in reaction to foreign influences.

The individual's active participation in correcting social problems originates from an ontological awakening about the subject who serves God. Donghak offers a radical vision of the

\footnotetext{
${ }^{7}$ Without considering a very specific political context of Donghak, some readers may consider it in potential danger of promoting exclusive nationalism. Donghak's anti-Western religion and Independent Movement were specific historical responses to Western and Japanese imperialism in the $19^{\text {th }}$ century. Donghak's spirit can be directed to resolving the most pressing social issues that make people suffer in every age. In the $21^{\text {st }}$ century, the world faces a different issue of environmental abuse and Donghak regards this issue as urgent now.
} 
subject. Lee (2014) articulates the central aspect of the practice of democratic ideals: The Shichun-ju theology is "the transcendent ideal and lure for new, liberating, and life-giving forms of human civilizational praxis ... [T] he restoration of Ultimate Energy's historical balance are the 'day-to-day forms of resistance' ... - which exemplify the rebounding of the suppressed selfcreative life-force of the othered multitude" (p. 241). Lee describes a radical democratic ideal that blurs the traditional binary of Heavenly Lord and human being, nor does it erect divisions among human beings due to social status, gender, or age. This new recognition of self-other generated a radical social movement by challenging existing hierarchical norms and practices. The peasant's movement 1894 was a great example of challenging the Neo-Confucian ideology that sustains the social hierarchy. Donghak has provided a theoretical and practical spirit to enact resistance (Setton, 2000).

Su-un's theology was not limited to proposing a metaphysical discourse about "Being;" it also participated in social transformation. Su-un theorizes authentic salvation is involved in creating Heavenly Earth (Ji-shang-chun-guk 地上天國) 'here and now,' rather than longing for a "real" life after resurrection and pursuing eternal rewards. During his lifetime, Su-un observed that Catholics chose to be persecuted while anticipating the 'real' life after death (Shin, 2005). Su-un's concepts of Heavenly Earth are genealogically linked with those found in Confucianism, Taoism, Buddhism, and Shamanism. Subscribing yet challenging this intellectual heritage, he criticized Catholic theology emphasizing resurrection and the "afterlife."

Active participation in the earthly, current sociopolitical, economic, and cultural issues motivates the creation of a "New Post-cosmic Opening" (Yoon, 2010, p. 325) or Gae-byeok. This vision of a new world here and now is possible only if the entire cosmos follows harmonious energy "without the artificial objection and excessive concentration of that cosmic 
energy in the hands of just a few or even one" (Lee, 2014, p. 226). Social activism for the new cosmic order aims to keep the balance of harmonious energy not controlled by a small number of the privileged. Su-un's promotion of critical consciousness about equal human dignity via Shichun-ju has become the motivation for multiple versions of social activism, including the 1894 Peasant's Liberation Movement, the Independent Movement during Japanese colonization, and advocacy for children's and women's equal rights. The meaning of creating heaven here and now is the motivation for creating a new, harmonious world without discrimination against any human beings. Donghak changed the previous view of women by recognizing their equal dignity and the important roles that women play in the family and society (Kim, 2006). The major social issue in Donghak concerns the ways in which people participate to correct social ills in their contemporary era.

Western liberation theology traditionally maintains the interpretation of the Christian gospel as equity-centered by focusing on the religious movements grounded in liberation and social transformation (Chung, 2007). Liberal theology tradition is compatible with Donghak's praxis for social transformation. Notably, Su-un provided an important theological, ontological understanding about life and the God-human-cosmos relationship. Given the sociopolitical context of the Joseon Dynasty, Su-un offered provocative insight about human dignity. He was eager to work towards a New World where the Ultimate Energy circulated harmoniously without any anthropocentric hindrances. The tradition of Donghak has spread widely through Korea's modern history, including the independence movement and education for children and women. New journals for women and children were published in the 1920s, and they have become the models for liberating Min-jung (the oppressed) in society. Su-un uses the term, "strengthening 
the nation and comforting people” (Boh-guk-ahn-min; 輔國安民) in articulating the concept of the Heavenly Earth (Ji-shang-chun-guk 地上天國).

Supporting the nation and comforting the people does not necessarily advocate exclusive nationalism. The major question was how to respond to the demands of greater social need. In $19^{\text {th }}$ century in Korea, achieving independence from Western and Japanese imperialism was the key issue with which Korean society had to contend. Given this situation, liberation theology is connected with the idea of "comforting people." Liberal theology and Donghak have similarities in that both are praxis-oriented theologies generating the foundations for social transformation. As elaborated with the concept of Gae-byeok, Donghak emphasizes individual-collective-cosmic interactions rather than exclusively relying on human conscious will. Donghak refuses the idea that social transformation is the direct result of humankind's autonomous efforts.

\section{Overcoming Gakjawishim and Creating a Cosmological Community (Dong-gui-ilche)}

Su-un believed social ills were generated from the selfish mind of the individual who does not consider the cosmic energy that creates harmonious community. Su-un witnessed the individualistic, egotistic mind embedded within Western imperialism. Grounded in Shi-chun-ju ontology, Su-un urges people to cultivate the pure mind of Hanullim to overcome the selfish mind (gak-ja-wi-shim 各自虏心). He highlights the importance of self-cultivation (Sushim$j u n g g i$ 守心正氣) as an important discipline for overcoming the selfish mind and returning to the pure mind of Hanullim.

Su-un elaborates, "if one would think about and never forget the bright Truth and Virtue of God and the incantation, one will unite with the Ultimate Energy (ji-gi) of God [Hanullim] and attain the perfect sagehood" (Kim \& Yoon, 2007, p. 11). This vision for salvation does not occur only on a personal level, but on a universal level, to unite with the Ultimate Energy, 
making cosmological communities. The practice of Sushim-junggi involves not only a subject's constant becoming that is completely attuned to Ultimate Energy; it is also an important practice to recognize cosmological community and overcome any selfish mind. Lee (2014) articulates the idea that the attainment of sagehood in Donghak arises from the mysterious eternal reciprocity between Hanullim-human. He states,

[T] he attainment of the ideal selfhood of the sage, or the divine transcendent, which is the attainment of the heart-mind of Lord Heaven, comes directly through the paradoxical trust in the indwelling of the heart-mind of Lord Heaven that is always already there in all of us and through the accompanying attitude of sincerity and reverence that is directly outward expansively to all creation (p. 223).

Thus, self-cultivation is not an individual's independent effort, as indicated by the Western humanistic approach. Rather, Donghak's self-cultivation is connected with the other's mind due to qi's characteristics of reciprocity and interconnected becoming (Lee, 2014). Yoon (2007a) also considers self-cultivation as part of the purpose of learning in Donghak. "Serving God [Hanullim] in me" indicates the subject lives by natural law. While traditional religion aims at pursuing the truth from the omnipotent Other, Donghak offers a different paradigm for the actualization of truth; people seek out the Tao that exists within the selves as a mode of serving God. The selfish mind (Gakja-wishim) is the phenomenon occuring when people forget God within themselves and follow their habitual life patterns. Thus, self-cultivation involves transforming independent self-seeking into the larger cosmic self by returning to the primordial connection to Hanullim. Returning together as One-ness is returning to the pure mind of God and creating a cosmological community. Su-un coins the term Dong-gui-il-che (同歸一體) as the final destination of self-cultivation that creates a harmonious cosmological community. This 
entire cosmos exists without artificial intervention and excessive concentration of power allotted to greedy administrators. The movement for Hanullim or Ultimate Energy's historical balance is a day-to-day form of resistance and it is exemplified by the rebounding self-creative life force of the oppressed multitude.

\section{Donghak in the $21^{\text {st }}$ Century:}

\section{Towards Diverse Curriculum Discourse on Equity and Social Transformation}

Thus far, I have examined the key concepts of Donghak and analyzed them to advance current educational discourses for equity and social transformation. A critical interpretation of Donghak provides a new discourse for self-other, desirable God-human-nature-cosmos relationship, and social transformation. Below, I suggest three major themes to consider for enriching educational theories and practices currently driven by market-oriented educational reform around the world.

\section{Rethinking the Self-Other Binary}

The new interpretation of self-other from Shi-chun-ju provides a new framework to rethink a hierarchical sociopolitical division in a pluralistic society. Donghak provides a new perspective to minimize any danger a normalized understanding of self/other creates in educational practices. Poststructuralist theorists in education have challenged the humanistic division of self-other by underscoring the interdependency of self-other. They challenge any fixed, transcendent understanding of self and other, let alone any universalized explication of collective identity. A linguistic and discursive construction of the subjectivity has shifted the self-other discourse by investigating historical, sociopolitical, and cultural interactions among the subjects (Miller, 2005). Thus, a liminal space is constantly (re)created by the self-other interaction and this generates a powerful insight regarding a society where the fixed border of 
self-other are blurred and deconstructed. Donghak extends the existing perspective on self-other by introducing a “my mind is your mind” (吾心師汝心) ontology.

Donghak extends the current educational discourse on equity by challenging fixed binaries of self/other, majority/minority, sameness/difference, and their hierarchical divisions. The "Oneness" of mind within God-human being, human-human, and human-nature interactions is an alternative way to think about the traditional Western self-other dichotomy. Within Shichun-ju, no hierarchy exists among God-humankind-nature-cosmos, let alone the hierarchy among humans due to the class, gender, and age. Donghak provides a strong framework to challenge the self-other bifurcation that perpetuates social hierarchies.

\section{Rethinking the Purpose of Learning: Self-cultivation as Curriculum Discourse}

Donghak offers a new vision for self-cultivation: the subject restores and keeps the harmonious balance in the cosmos by returning to the Tao of God he or she serves. In the traditional Confucian tradition, self-cultivation and acquiring sagehood is the ultimate goal of studying. Highly influenced by Neo-Confucianism, Donghak also highlights self-cultivation as a major goal of studying. As I indicated in the discussion, self-cultivation in Donghak underscores that each person should be reminded of the pure Hanullim in himself or herself by repeating incantation and meditations. The Donghak movement was a resistance against the disharmony or imbalance in a society where selfishness controls the whole society, driven by corrupt leaders and foreign imperialism.

The major purpose of education in Donghak is to practice self-cultivation by asking the crucial question of how to correct social wrongs; the answer involves purifying one's mind (守心正氣). The current predominant curriculum discourse underscores increasing numeracy skills and literacy as the major tools to Race to the Top in the competitive global market. 
Knowledge is limited to an entity existing outside of the subject and the goal of education is to accumulate as much knowledge as possible. No emphasis exists on self-cultivation in an educational paradigm influenced by the logic of competition and the market-oriented values of producing maximum outcomes with minimal inputs. Donghak provides different definitions of pedagogy and the purpose of acquiring knowledge. Important knowledge in life is acquired by self-cultivation, clearing one's mind, and returning to the pure mind of Hanullim. In education, the search for truth or knowledge thus exists inside of the subject and is not imposed from outside of the subject. Donghak provides the provocative idea of returning to self in considering the truth and knowledge, which is an important new direction in education.

\section{Eco-centered Curriculum in the $21^{\text {st }}$ Century}

The emphasis on environment and sustainability in education has been a major trend in developing an eco-centered curriculum theory. The anthropocentric paradigm is challenged by rethinking the concept of nature to expose the dangers of looking at nature as an object to be controlled. Donghak provided a framework to create a new order in the chaotic universe on the cosmic level in $19^{\text {th }}$ and $20^{\text {th }}$ century Korea (Yoon, 2004). The ontology of human being is related with cosmology in Donghak. The relations among God-human-nature-cosmos are conceived of as relationships of equals without hierarchal strata. Conceiving of a cosmological community means considering the cosmic energy as one (混元一氣); humans should expend their efforts to restore this unified cosmic spirit. The cosmos is a universal sibling of human beings because the cosmos itself is nothing but diverse formats of qi. This equal understanding of spiritual $q i$ is the foundation of regarding God, human, and nature all as part of universal cosmology (Oh, 1989, p. 155). Thus, the interconnection and equal relations among God-human- 
nature-cosmos in Donghak go beyond the anthropocentric understanding of human-nature relation.

This ecology-centered curriculum differs from the existing anthropocentric hierarchy that considers nature as the tool for human civilization. Humankind should respect every creature as divine, as indicated in Shi-chun-ju theology. Donghak articulates the ideal that all living and nonliving things co-exist harmoniously. The one who serves Hanullim would treat nature as he or she would treat his or her body (Kim, 2002). Donghak teaches us to transfer the "death life" of violence and alienation to the "living life" of respect and consideration of lives. Donghak meaningfully provides life-oriented thoughts as an important paradigm to restructure the cosmic community (Kim, 2007). The emphasis on co-living in Donghak, with the ontological analysis on God-human-nature-cosmos relationship, enriches existing discourse on ecology education in the $21^{\text {st }}$ century. 


\section{References}

Chung, K. (2007). The Donghak concept of God/heaven: Religion and social transformation. New York, NY: Peter Lang Publishing.

Freire, P. (1970). Pedagogy of the oppressed. New York, NY: Continuum.

Han, H. S. (2010). Practical philosophy of Choe Je-woo implied in Donghak. Minjoksasang [National Ideology], 4(2), 181-207.

Jung, H. (2014). Mystical form and life education as healing of Tonghak. Jonggyogyoukhakyeongu [Religious Education Studies], 46, 67-96.

Kallander, G. L. (2013). Salvation through dissent: Tonghak heterodoxy and early modern Korea. Honolulu, HI: University of Hawaii Press.

Kim, C. S. (2002). Donghak: Towards life and spirituality. Korea Journal, 42(4), 158-186.

Kim, Y. O. (2004). Doalsimdúk: Donggyeongdaejeon [Classics of Eastern Learning \& Pletharchia]. Seoul, Korea: Tongnamu.

Kim, M. J. (2006). The changed view of womanhood by Donghak Chondogyo.Hankuksahakbo [Korean History Review], 25, 357-390.

Kim, Y. (2007). Wurihakmunuroseoui Donghak [Donghak as our studies]. Seoul, Korea: Chaeksesang.

Kim, Y. (2012). Donghak's Gaebyeok thought and new civilization. Hankukjonggyo [Korean Religious Studies], 35, 57-85.

Kim, Y. C. \& Yoon, S. S. (Trans.). (2007). Chondogyo scripture: Donggyeong Daejeon (Great Scripture of Eastern learning). Lanham, MD: University Press of America.

Lee, H. (2014). Spirit, qi, and the multitude: A comparative theology for the democracy of creation. New York, NY: Fordham University Press. 
Miller, J. L. (2005). Sounds of silence breaking: Women, autobiography, curriculum. New York, NY: Peter Lang.

Oh, M. H. (1989). Su-un Choi, Je-u's perspective on Human: New-human through shi-jing-chi. Donghakyeongu [Donghak Studies], 4, 115-175.

Oh, M. H. (2003). Autonomous man and formation of public sphere in Donghak. Korean Political Science Review, 37(4), 29-54.

Pinar, W. F., Reynolds, W. M., Slattery, P., \& Taubman, P. M. (1995). Understanding curriculum: An introduction to the study of historical and contemporary curriculum discourses. New York, NY: Peter Lang.

Ra, D. K. (2002). The Donghak movement for the rural people. Donghakyeongu [Donghak Studies], 12, 121-135.

Ricci, M. (1985). The true meaning of the Lord of Heaven (T'ien-chu Shih-i). (Trans. D. Lancashire \& P. H. Kuo-chen). St. Louis, MO: The Institute of Jesuit Sources.

Setton, M. (2000). Confucian populism and egalitarian tendencies on Tonghak thought. East Asian History, 20, 121-144.

Shin, Y. (2005). Donghaknongminhyukmyeongwundonguisaheoisa [Social history of Donghak peasant revolutionary movement of 1894 in Korea]. Seoul, Korea: Jisiksanupsa [Knowledge Industry Co.].

Yoon, S. S. (2004). Dong Hak foundation viewed from the standpoint of civilization history. Hankukúnuhmúnhakhakheoi [Korean Language \& Culture], 26, 83-95

Yoon, S. S. (2007a). Serving, treat, and respect living. Donghakyeongu [Donghak Studies], 22, $23-47$. 
Yoon, S. S. (2007b). Religious thought and practice movement: The relationship and implication. Hankukunuhmunhwa [Korean Language \& Culture], 33, 157-178.

Yoon, S. S. (2010). Studies of the New Post-cosmic creation of Donghak. Hankukúnuhmúnhakhakheoi [Korean Language \& Culture], 42, 325-346. 